\title{
Common Medicinal Plants Species Found at Burned and Unburned Areas of Klias Peat Swamp Forest, Beaufort, Sabah Malaysia
}

Andy Russel Mojiol (Corresponding author)

School of International Tropical Forestry

Universiti Malaysia Sabah

Locked Bag 2073, Kota Kinabalu 88999 Sabah, Malaysia

Tel: 60-88-320-118 E-mail: rmojiol@yahoo.co.uk

Audrey Adella

School of International Tropical Forestry

Universiti Malaysia Sabah

Locked Bag 2073, Kota Kinabalu 88999 Sabah, Malaysia

Tel: 60-88-320-000 E-mail: schumey_adel@yahoo.com

Julius Kodoh

School of International Tropical Forestry

Universiti Malaysia Sabah

Locked Bag 2073, Kota Kinabalu 88999 Sabah, Malaysia

Tel: 60-88-320-000Ｅ-mail: Julius@ums.edu.my

Walter Lintangah

School of International Tropical Forestry

Universiti Malaysia Sabah

Locked Bag 2073, Kota Kinabalu 88999 Sabah, Malaysia

Tel: 60-88-320-000 E-mail: walterj1@ums.edu.my

Razak Wahab

School of International Tropical Forestry

Universiti Malaysia Sabah

Locked Bag 2073, Kota Kinabalu 88999 Sabah, Malaysia

Tel: 60-88-320-000 E-mail: drrazakw@ums.edu.my

The research is financed by The Ministry of Science, Technology and Invention, Malaysia, under the Seed Money Fund (SMS0066-SG-2008)

\section{Abstract}

The aims of this study is to survey the abundance and diversity of medicinal plants found in burned and unburned areas of klias peat swamp forest, Beaufort. There are 16 plots established with the size of $25 \mathrm{~m} \times 25 \mathrm{~m}$ for each plot with total area of 1 ha. All the plots were established using random sampling method and Simpson's Index and Important Value 
(IV) were used to determine the diversity and abundance of the species. The result of the study shows that 11 species have been found in burned area while 10 species at unburned area. The most common medicinal plant species are identified as Stenochlaena palustris, Melastoma malabathricum, Lygodium flexuosum, and Clidemia hirta. The most abundant medicinal plant species found in burned area was Stenochlaena palustris with 185 percent (\%). While in unburned area, the most abundant medicinal plants were Hedychium longicornutum and Lygodium flexuosum with 55 percent each. Simpson's Index is higher with 0.55 in burned area compared in unburned area with only 0.14 . Where when the value of Index increases, the diversity will decrease and this proved that diversity of medicinal plants in unburned area was slightly higher than the burned area. This situation might be caused by the previous land clearing due to burning and small scales landuses activities at the edges of Klias peat swamp forest. More research is needed in order to gain more precise data

Keywords: Medicinal plants, Peat swamp forest, Abundance and diversity, Sabah

\section{Introduction}

Plants contribute many uses for human since long time ago. Many species of plants are used as part of the treatment of diseases and for the well-being of man. Medicinal plant is a plant that used in the treatment of diseases and to maintain health (Lewis \& Elvin-Lewis, 2003). According to the latest reports, there are about 1200 species of plants in Malaysia that potentially had a pharmaceutical or medicinal value (Khatijah, 2006).

In Malaysia, around 2,000 plants species have therapeutic characteristics and can be use in traditional treatment (Rukayah, 2006). Usually plants such as shrubs, bushes and wild flower have the pharmaceutical value (Wiart, 2000). Wild plants are plants that grow wildly in their habitat without human involvement. But recently, some medicinal plants faced extinction because of the disturbance in their habitat such as forest fire, logging or encroachment by human (Sabah Forestry Department, 2005). According to Mojiol (2006), humans are the agents of extinction to the natural environment. They caused the extinction by altering habitats (mainly forests, but also fresh waters and wetlands), overexploiting and introducing an exotic species.

Medicinal plants were divided into herbs and woody plants. Medicinal plant contains of many pharmacologically active compounds (Khatijah, 2006). Some medicinal plants' part like leaves, barks, roots and fruits can be used in treatment of diseases (Fasihuddin \& Ghazally, 2001). Nowadays, because of lack of knowledge in importance of plants, forest has been disturbed where unmanaged logging happened everywhere. Klias peat swamp forest also faced the same situation. Since there is no data of medicinal plants yet being identify at KFR. This study had been carried out to give guidelines for researchers or students on species of medicinal plant can be found in burned and unburned area in Klias Peat Swamp Forest Reserve (KFR).

The major objectives of this study are to compare the species abundance and diversity of medicinal plants in burned and unburned area and to list and identify potential medicinal plants found in burned and unburned area at Klias Forest Reserve.

\subsection{Study Site: Klias Forest Reserve, Beaufort, Sabah}

The study has been done in Klias Peat Swamp Forest Reserve or also known as Klias Forest Reserve (KFR). Klias Forest Reserve was a Class 1 protection forest with an area of 3,630 ha and located within the Klias Peninsula. It was gazetted as a Class 1 protection forest in 1984 under jurisdiction of the Sabah Forestry Department. Its latitude was $5^{\circ}$ $22^{\prime} 60 \mathrm{~N}$ with longitude $115^{\circ} 45^{\prime} 0 \mathrm{E}$. The average annual rainfall was about $3,300 \mathrm{~mm}$ but varied between 2,300 to 4,700 mm according to 20 years of observations.

The $\mathrm{pH}$ in Klias peat swamp forest was around 3.66 to 3.56. This $\mathrm{pH}$ showed an acidic soil where the peat swamp was due to waterlogged soils condition which prevents dead leaves and wood from fully decomposing, which over time creates thick layer of acidic peat. Temperature in Klias Forest Reserve was around $26^{\circ} \mathrm{c}$ to $30^{\circ} \mathrm{c}$ and had experienced with peat fires during El Niño in 1998 and logged over before this. So far, KFR was divided into burned and unburned area (Sabah Forestry Department, 2005).

KFR was a part of the wetland ecosystems which included floras and faunas. The freshwater swamp forest, nipah swamps, peat swamps forest and kerangas, secondary dry land forest and mangroves were the habitats that can be found in this area. Various communities reside in the areas bordering the Klias Forest Reserve. Among them were the villagers of $\mathrm{Kg}$. Bukau and $\mathrm{Kg}$. Pulaimanang with an estimated combined population of 1, 000 people. Both of these villagers were predominantly Muslim. According to $\mathrm{Ng}$ (2000), about 60 percent of communities in Beaufort are Bisaya, 14 percent of Kadazan-Dusun, 9 percent Murut, 3 percent Chinese and others with 2 percent.

\section{Materials \& Methods}

\subsection{Experimental Design and Field Procedure}

Data collection process for abundance of medicinal plants in Klias Peat Swamp Forest has successfully completed by applying inventory method. Inventory method with a random sampling was done because it is the most suitable 
inventory method to be use in this research. Random sampling method can be represented the whole forest area and also the easiest way to apply. About 1 ha plot was involved in this research (consisted of 8 subplots in burned and 8 subplots in unburned areas respectively). Each subplot was plotted with plot size $25 \mathrm{~m} \times 25 \mathrm{~m}$ for each area. One sub-plot equals to $0.0625 \mathrm{ha}$. The abundance of the species is referring to the measurement of the amount of a species in a sample plot. The abundance provides information about the density, the frequency and the coverage of the species that can be determined in plots. The calculation of important values incorporates with the relative density, relative coverage and relative frequency of the species. Besides calculating the abundance (density, coverage and frequency) of fern species, the index of diversity of fern species in Klias Forest Reserve both in burned and unburned area were also calculated. By using the Simpson index, the comparison of the diversity of fern species in burned and unburned area of Klias Forest Reserve is also counted.

\section{Results and Discussion}

\subsection{Abundance of Medicinal Plant in Burned Area}

Referring to the Table 1, Stenochlaena palustris was the highest important value (IV) than other species in burned area with 185 percent. According to Rukayah, 2006, Stenochlaena palustris's habitat usually in peat swamp, opened area, and soil which was rich of sulfate acid. Species with the lowest IV percentage was Nephenthes sp. From Nepentaceae or also known with as Periuk Kera with 2 percent. Nephenthes sp. or Periuk kera was the lowest abundant species in burned area. Nephenthes sp. usually lived in moist and shaded area. Burned area was not a suitable habitat for Nephenthes sp. to grow because of the acidic soil and an opened area.

\subsection{Abundance of Medicinal Plant in Unburned Area}

In unburned area, the most abundant medicinal plants were Hedychium longicornutum and Lygodium flexuosum with 55 percent each (Table 2). According to Rukayah (2006), Hedychiumlongicornutum's and Lygodium flexuosum's habitat was in the forest and bushes. Therefore, unburned area or natural habitat was the most suitable place for Hedychium longicornutumand Lygodium flexuosum to grow. Labisa pumila was the lowest abundant species in unburned area. According to De Padua et. al (1999), Labisa pumila's habitat was in shaded area. This species cannot grow in an opened area but can grow successfully in loam soil that rich with organic structure and humus. Unburned area was the most suitable place for Labisa pumila to grow. But, somehow the abundance of Labisa pumila was low in unburned area because the local communities who reside near the KFR happened to collect this plant for consumption and medicinal purpose.

According to the Ketua Kampung of Kg. Bukau stated that this plant was use by the local to release pain after giving child birth and give energy especially for woman who was pregnant. According to Japar (Pers. com: 2007), local people intend to enter Klias Forest Reserve for fishing and collect forest produce for their own use especially for food, shelter and medicine. This fact supported by Timothy (2003) in his report about Current Land-use and Relevant Planning Instruments Surrounding the Klias Peninsula. Where according to Timothy (2003), unsustainable land-uses surrounding peat swamp forest of Klias Peninsula can be a destructive to the environment if not controlled, such as fishing, hunting and extraction of forest produce that have been known.

\subsection{Comparison of Diversity between Burned and Unburned Area}

The Simpson's Index showed a value of 0.55 in burned areas while 0.14 in unburned areas. According to Magurran (2005), the value of diversity (D) in Simpson's Index was between 0 and 1. As the diversity indexes (D) increases, the diversity will decrease. Referring to the graph below, burned area had slightly highest Simpson's Index where the index was nearly to one. Further while, unburned area showed a lower index than Simpson's Index in burned area. This means, the diversity of medicinal plant in unburned area was higher than in burned area.

Referring to Figure 4, Simpson's Index in unburned area was lower than in burned area. This was also means that medicinal plants in burned area were denser with individually species compared to unburned area. The abundant of medicinal plants was higher with Stenochlaena palustris colonizing the burned area. As mentioned before, burned area had experienced peat fire during El Niño in 1998. According to Whitmore (1991), rate of regeneration in burned area was higher because this area was an opened area. Therefore, there will be more plants such as shrubs and herbs that have medicinal value grow in burned area. In addition, the abundance of medicinal plant in unburned area was lower because of the local people activities who collect the medicinal plant within the unburned area in KFR. As mentioned before, local people intend to enter Klias Forest Reserve to fishing and collect forest produce for their own use especially for food, shelter and medicine (Japar, Pers. com, 2007). Somehow, this activity also contributes in decreasing of the number of medicinal plants collected in unburned area.

\section{Conclusion}

The abundance and diversity of medicinal plants in both burned and unburned area in Klias Forest Reserve has successfully collected after the entire inventory had been done. The total of medicinal plant species in both burned and 
unburned area were 21 species. Important value was used to count the abundance of medicinal plants that successfully collected in both areas. Density, frequency, and coverage also gained from the inventory.

The objectives of this study were successfully achieved. All information to determine the abundance in both areas was gained. The abundance of medicinal plants in both areas was differing from the number of species found. There were eleven (11) species of medicinal plants found in unburned area while ten (10) species of medicinal plants found in burned area. In unburned area, the most abundant medicinal plants were Hedychium longicornutum and Lygodium flexuosum while Labisa pumila was the lowest abundant species in this area.

In burned area, the most abundant medicinal plant was Stenochlaena palustris while Nephenthes sp. or Periuk kera was the lowest abundant species in this area. Medicinal plants in unburned area were more diverse than medicinal plant that founded in burned area where random sampling method was used to gain all data needed.

Medicinal plants that were successfully collected in this study including Stenochlaena palustris, Chromolaena odorata, Melastoma malabathricum, Lygodium flexuosum, Cyperus rotundus, Clidemia hirta, Passiflora foetida, Hedychium longicornutum, Peperomia pellucida, Nephenthes sp, Imperata cylindrical, Licuala spinosa, Etlingera littoralis, Labisa pumila and Mikania cordota. The total area that included using random sampling method was still not enough to cover the whole area of Klias Forest Reserve. Therefore, advance study recommended to covers the area that not been included in this study.

\section{Acknowledgements}

We would like to thank the Site Manager of Klias Forest Reserve, Mr. Alexander Gervasius for extending his permission for us to conduct this research. We are also very much indebted to various people who have helped in data collection especially to the Security and Development Committee of Kg. Bukau, Mr. Jailani who helped us a lot during data collection process. Finally, we are very grateful to Universiti Malaysia Sabah especially to School of International Tropical Forestry for the support given in conducting this study.

\section{References}

De Padua L.S., Bunyapraphatsara N. and Lemmens R.H. (1999). Plant Resources of South-East Asia 12 (1) Medicinal and Poisonous Plants 1 ,26. Backhuys Publishers, Leiden, the Netherlands.

Fasihuddin, A. \& Ghazally, I. (2001). Medicinal Plants used by Kadazandusun Community around Crocker Range National Park. ASEAN Review of Biodiversity and Environmental Conservation (ARBEC).

Japar, J. (2007). Personal Communication. Klias, Sabah. (Mr Japar Jailani is the Security and Development Committee of Kg. Bukau in Klias, Sabah)

Khatijah H. (2006). Anatomical Atlas of Malaysian Medicinal Plants. Vol 1. Malaysia, Universiti Kebangsaan Malaysia Bangi, Selangor.

Lewis H.W and Elvin-Lewis, F.P.M. (2003). Medical Botany, Plants Affecting Human Health Second Edition,1. John Wiley \& Sons.

Magurran E. A.. (2005). Measuring Biological Diversity. Blackwell Publishing, Australia.

Mojiol A.R. (2006). Ecological Landuse Planning and Sustainable Management of Urban and Sub-urban Green Areas in Kota Kinabalu, Malaysia. Cuvillier Verlag, Goettingen, Germany.

Ng W.T. (2000). Penilaian Sosio-ekonomi Bagi Corak dan Produk Hutan Tani Oleh Komuniti Perhutanan di Hutan Simpan Klias, Sabah. Tesis SmSn. (Kep). Universiti Malaysia Sabah. (Unpublished).

Rukayah Aman. (2006). Tumbuhan Liar Berkhasiat Ubatan. Dewan Bahasa dan Pustaka, Kuala Lumpur.

Sabah Forestry Department. (2005). Klias Peat Swamp Forest, Sabah, Malaysia: Hydrological Process and Strategies for Water Management, Sabah Forestry Deparment.UNDP/GEF and Danida Klias Peat Swamp Forest Conservation Project. Sabah, Malaysia.

Timothy M.P. (2003). Review of Current Land-use and Relevant Planning Instruments Surrounding the Klias Peninsula. UNDP/GEF Funded Project.

Whitmore T.C. (1991). Hutan Hujan Tropika Di Timur Jauh. (terj.). Dewan Bahasa dan Pustaka, Kuala Lumpur.

Wiart C. (2000). Medicinal Plants of Southeast Asia. Malaysia. Pelanduk Publications. 
Table 1. Important Value (IV) of Medicinal Plant Species in Burned Area

\begin{tabular}{|c|c|c|c|c|c|c|c|}
\hline No. & Family & Species & Local name & $\mathrm{RD}(\%)$ & RF(\%) & RC(\%) & IV(\%) \\
\hline 1 & Polypodiaceae & $\begin{array}{l}\text { Stenochlaena } \\
\text { palustris }\end{array}$ & Lembiding & 42 & 34 & 109 & 185 \\
\hline 2 & Melastomaceae & $\begin{array}{l}\text { Melastoma } \\
\text { malabathricum }\end{array}$ & Senduduk & 12 & 14 & 6 & 32 \\
\hline 3 & Schizaeaceae & Lygodium flexuosum & Ribu-ribu besar & 2 & 12 & 3 & 17 \\
\hline 4 & Cyperaceae & Cyperus rotundus & $\begin{array}{l}\text { Rumput halia } \\
\text { hitam }\end{array}$ & 1 & 12 & 0 & 13 \\
\hline 5 & Melastomaceae & Clidemia hirta & Senduduk paksa & 1 & 12 & 0 & 13 \\
\hline 6 & Passifloraceae & Passiflora foetida & Letup-letup & 1 & 11 & 0 & 12 \\
\hline 7 & Zingerberaceae & $\begin{array}{l}\text { Hedychium } \\
\text { longicornutum }\end{array}$ & Kunyit hantu & 0 & 9 & 0 & 9 \\
\hline 8 & Asteraceae & $\begin{array}{l}\text { Chromolaena } \\
\text { odorata }\end{array}$ & $\begin{array}{l}\text { Pokok kapal } \\
\text { terbang }\end{array}$ & 1 & 7 & 1 & 9 \\
\hline 9 & Piperaceae & Peperomia pellucida & Ketumpangan air & 1 & 7 & 0 & 8 \\
\hline 10 & Nepentaceae & Nephenthes sp. & Periuk kera & 0 & 2 & 0 & 2 \\
\hline & & & TOTAL & 61 & 120 & 119 & 300 \\
\hline
\end{tabular}

$\mathrm{RD}=$ Relative dominant. $\quad \mathrm{RC}=$ Relative Coverage. $\quad \mathrm{RF}=$ Relative Rrequency.

Table 2. Important Value (IV) of Medicinal Plant Species in Unburned Area

\begin{tabular}{|l|l|l|l|c|c|c|c|}
\hline No. & Family & Species & Local name & $\mathbf{R D ( \% )}$ & $\mathbf{R F ( \% )}$ & $\mathbf{R C ( \% )}$ & $\mathbf{I V ( \% )}$ \\
\hline 1 & Zingerberaceae & $\begin{array}{l}\text { Hedychium } \\
\text { longicornutum }\end{array}$ & Kunyit hantu & 15 & 21 & 19 & 55 \\
\hline 2 & Schizaeaceae & Lygodium flexuosum & Ribu-ribu besar & 3 & 21 & 31 & 55 \\
\hline 3 & Gramineae & Imperata cylindrica & Lalang & 5 & 11 & 34 & 40 \\
\hline 4 & Palmae & Licuala spinosa & Palma & 4 & 11 & 23 & 38 \\
\hline 5 & Zingerberacea & Etlingera littoralis & Tepus & 3 & 11 & 9 & 23 \\
\hline 6 & Annonaceae & Ellipeia cuneifolia & Kayu Bibiris & 5 & 4 & 13 & 22 \\
\hline 7 & Melastomaceae & Clidemia hirta & Senduduk paksa & 2 & 11 & 4 & 17 \\
\hline 8 & Rubiaceae & $\begin{array}{l}\text { Lasianthus } \\
\text { inaequalis }\end{array}$ & Pikolas & 1 & 11 & 3 & 15 \\
\hline 9 & Polypodiaceae & $\begin{array}{l}\text { Stenochlaena } \\
\text { palustris }\end{array}$ & Lembiding & 1 & 11 & 3 & 15 \\
\hline 10 & Compositae & Mikania cordota & Selaput tunggul & 0 & 4 & 10 & 14 \\
\hline 11 & Myrsinaceae & Labisa pumila & Kacip fatimah & 0 & 3 & 3 & 6 \\
\hline & \multicolumn{2}{|r|}{ TOTAL } & $\mathbf{3 9}$ & $\mathbf{1 1 9}$ & $\mathbf{1 5 2}$ & $\mathbf{3 0 0}$ \\
\hline
\end{tabular}

$\mathrm{RD}=$ Relative dominant. $\quad \mathrm{RC}=$ Relative Coverage. $\quad \mathrm{RF}=$ Relative Rrequency. 
Table 3. Classification, Identification and Uses of Medicinal Plant

\begin{tabular}{|c|c|c|c|c|}
\hline No. & Family & Scientific name & Local name & Uses \\
\hline 1 & Asteraceae & Chromolaena odorata & Pokok kapal terbang & $\begin{array}{c}\text { Thrombogenic, stop } \\
\text { bleeding }\end{array}$ \\
\hline 2 & Compositae & Mikania cordota & Selaput tunggul & $\begin{array}{l}\text { Stomach pain and } \\
\text { dysentery }\end{array}$ \\
\hline 3 & Cyperaceae & Cyperus rotundus & Rumput halia hitam & $\begin{array}{c}\text { Indigestion, Skin } \\
\text { diseases, } \\
\text { Irregular } \\
\text { menstruation }\end{array}$ \\
\hline 4 & Gramineae & Imperata cylindrica & Lalang & $\begin{array}{c}\text { Hemoptysis, } \\
\text { hematuria, } \\
\text { and nose bleeding }\end{array}$ \\
\hline 5 & Melastomaceae & $\begin{array}{c}\text { Melastoma } \\
\text { malabathricum }\end{array}$ & Senduduk & $\begin{array}{l}\text { Diarrhoea and } \\
\text { dysentery }\end{array}$ \\
\hline 6 & Melastomaceae & Clidemia hirta & Senduduk paksa & Relieves heart burn \\
\hline 7 & Myrsinaceae & Labisa pumila & Kacip Fatimah & $\begin{array}{l}\text { Release pain after } \\
\text { giving } \\
\text { birth especially for } \\
\text { woman }\end{array}$ \\
\hline 8 & Nepentaceae & Nephenthes sp. & Periuk kera & Diarrhea and fever \\
\hline 9 & Palmae & Licuala spinosa & Palma & Dehydration \\
\hline 10 & Passifloraceae & Passiflora foetida & Letup-letup & $\begin{array}{c}\text { Thrombogenic, stop } \\
\text { bleeding }\end{array}$ \\
\hline 11 & Piperaceae Cure & Peperomia pellucida & Ketumpangan air & $\begin{array}{c}\text { eye ache, fever, } \\
\text { stomach ache }\end{array}$ \\
\hline 12 & Polypodiaceae & $\begin{array}{c}\text { Stenochlaena } \\
\text { palustris }\end{array}$ & Lembiding & Fever, skin disease \\
\hline 13 & Schizaeaceae & Lygodium flexuosum & Ribu-ribu besar & $\begin{array}{c}\text { Hemoptysis, cough, } \\
\text { fever }\end{array}$ \\
\hline 14 & Zingerberaceae & $\begin{array}{c}\text { Hedychium } \\
\text { longicornutum }\end{array}$ & Kunyit hantu & Fever \\
\hline 15 & Zingerberaceae & Etlingera littoralis & Tepus & $\begin{array}{c}\text { Fever and stomach } \\
\text { ache }\end{array}$ \\
\hline 16 & Annonaceae & Ellipeia cuneifolia & Kayu bibiris & Fever \\
\hline 17 & Rubiaceae & Lasianthus inaequalis & Pikolas & Fever \\
\hline
\end{tabular}




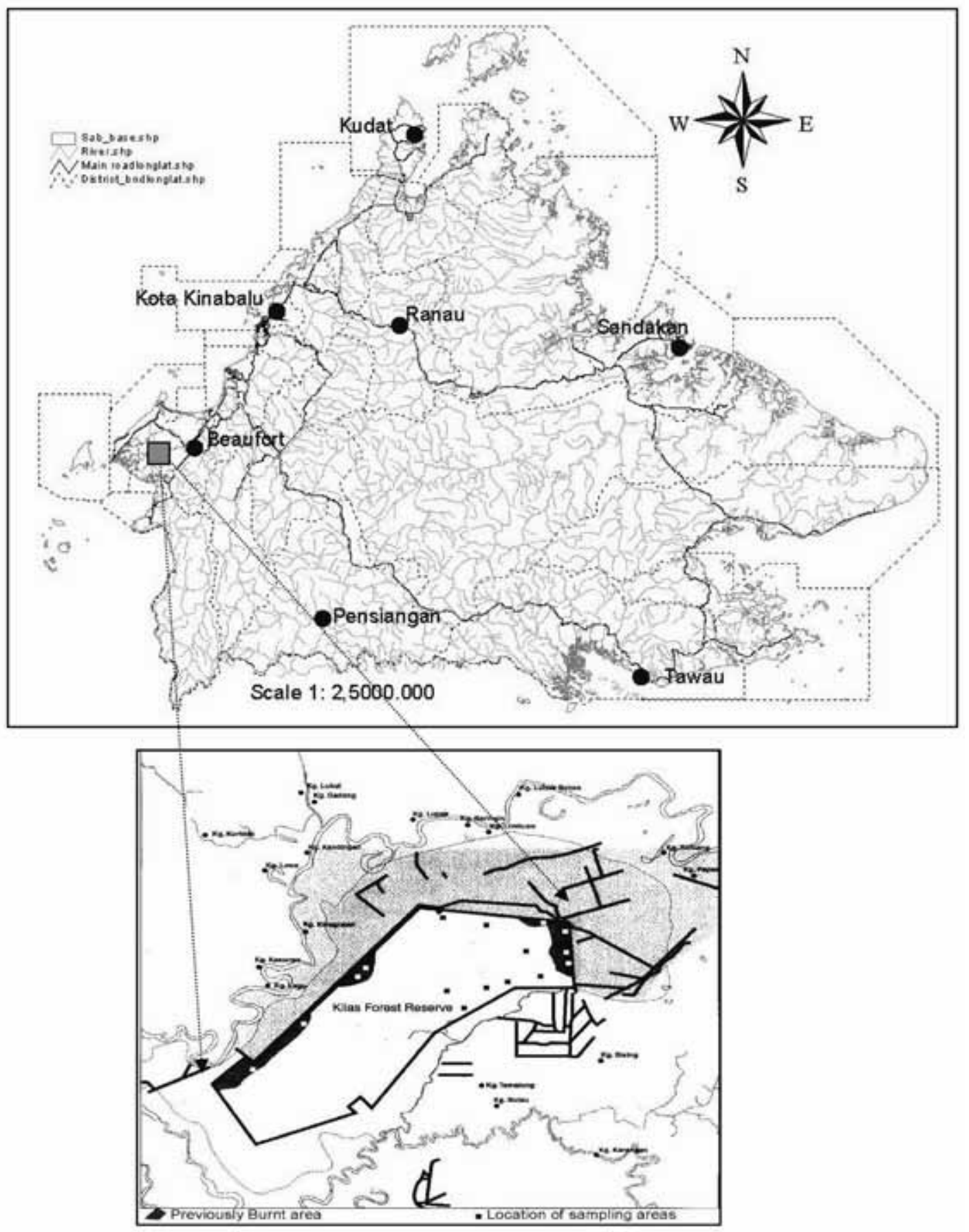

Figure 1. Location of Klias Peat Swamp Forest, Beaufort, Sabah Malaysia.

This figure shows the location of sixteen (16) randomly selected sampling plots at Klias Peat Swamp Forest 